\title{
The genus Afrosyrphus Curran (Diptera, Syrphidae), with a description of a new species
}

\author{
Ximo MENGUAL ${ }^{1, *}$, Axel SSYMANK ${ }^{2}$, Jeffrey H. SKEVINGTON ${ }^{3}$, \\ Menno REEMER ${ }^{4} \&$ Gunilla STÅHLS ${ }^{5}$
}

1,2 Zoologisches Forschungsmuseum Alexander Koenig, Leibniz-Institut für Biodiversität der Tiere, Adenauerallee 160, D-53113 Bonn, Germany.

${ }^{2}$ Falkenweg 6, 53343 Wachtberg, Germany.

${ }^{3}$ Canadian National Collection of Insects, Arachnids and Nematodes, Agriculture and Agri-Food Canada, K.W. Neatby Building, 960 Carling Avenue, Ottawa, Ontario, K1A 0C6, Canada.

${ }^{3}$ Department of Biology, Carleton University, 1125 Colonel By Drive, Ottawa, Ontario, K1S 5B6, Canada.

${ }^{4}$ Naturalis Biodiversity Center, P.O. Box 9517, 2300 RA Leiden, the Netherlands.

${ }^{5}$ Finnish Museum of Natural History, Zoology unit, Pohjoinen Rautatiekatu 13, P.O. Box 17, FI-00014 University of Helsinki, Finland.

${ }^{*}$ Corresponding author: x.mengual@1eibniz-zfmk.de

${ }^{2}$ Email: ssymanka@t-online.de

${ }^{3}$ Email: jhskevington@gmail.com

${ }^{4}$ Email: Menno.Reemer@naturalis.nl

${ }^{5}$ Email: gunilla.stahls@helsinki.fi

${ }^{1}$ urn:1sid:zoobank.org:author:A509310D-B567-4830-B8A4-BCB139BB8768
${ }^{2}$ urn:1sid:zoobank.org:author:58B9D453-586C-4B08-BAD6-BCC606E3D654
${ }^{3}$ urn:1sid:zoobank.org:author:7731BE76-3A89-4F55-8362-07CBE2F99136
${ }^{4}$ urn:Isid:zoobank.org:author:9086F7C0-622F-4E5F-BDEB-14E71A027BEE
${ }^{5}$ urn:1sid:zoobank.org:author:D19B1262-503A-48E2-91AE-F99D0F2EA3A3

\begin{abstract}
The flower fly genus Afrosyrphus Curran, 1927 (Diptera, Syrphidae) is revised and a new species, Afrosyrphus schmuttereri sp. nov., from Kenya and Uganda is described. Diagnoses, illustrations, DNA barcodes and known distributional data are provided for the two species of this genus, as well as an identification key. A critical review of the published literature is also provided.
\end{abstract}

Keywords. Flower flies, hover flies, DNA barcoding, identification key, Afrotropical Region.

Mengual X., Ssymank A., Skevington J.H., Reemer M. \& Ståhls G. 2020. The genus Afrosyrphus Curran (Diptera, Syrphidae), with a description of a new species. European Journal of Taxonomy 635: 1-17.

https://doi.org/10.5852/ejt.2020.635

\section{Introduction}

Curran (1927) described a new genus of flower flies (Diptera Linnaeus, 1758: Syrphidae Latreille, 1802) based on a single male collected a few years earlier in the Democratic Republic of the Congo (DRC). This new genus and new species was named Afrosyrphus varipes Curran, 1927. The type specimen was collected in Kisangani in 1915 by Lang and Chapin, members of The American Museum of Natural 
History Expedition (1909-1919). Later on, in a series of articles dedicated to African Syrphidae (Curran 1938a, 1938b, 1939a, 1939b), another two males and a female of $A$. varipes from the same country, but collected by Bequaert between 1913 and 1915, were studied by Curran (1938b). For many years (until Schmutterer 1974) these were the only known specimens of this very peculiar, stingless bee-mimicking fly, with elongated antennae, rather pilose body, and metaleg with dense dorsal and ventral fringes of long pile.

At the time of the original description, Curran (1927) could not relate his new genus and species to other known genera and suggested some morphological relationship with Syrphus Fabricius, 1775 (e.g., ventral calypter with long, erect pile) and with Chrysotoxum Meigen, 1803 (e.g., elongated antennae). Years later, Curran (1938b) mentioned the resemblance between this taxon and some species of Leucozona (Ischyrosyrphus) Bigot, 1882. Hull (1949) gave a short diagnosis for Afrosyrphus, and years later Vockeroth (1969) redescribed the genus and described the male genitalia for the first time. Based on characters of the male genitalia, Vockeroth (1969) suggested a close generic affinity with Epistrophe Walker, 1852.

Interestingly, while studying predatory syrphid larvae in Kenya, Schmutterer (1974) found abundant larvae of Afrosyrphus feeding on different species of aphids (Hemiptera Linnaeus, 1758: Sternorrhyncha Amyot \& Serville, 1843: Aphidoidea Geoffroy, 1762), which were reared into adults, identified at the time as $A$. varipes. These were the first specimens of Afrosyrphus reared from larvae, but also the first records from Kenya and the first time that the genus had been collected since 1915. In the Afrotropical Catalogue, Smith \& Vockeroth (1980) listed A. varipes from DRC, Kenya, Angola and South Africa, but no source for the two latter country citations was given (see also Dirickx 1998). More recently, Ssymank (2012) collected four specimens of A. varipes, a male and three females, in Cameroon (Province Adamaoua, Dept Vina).

The aim of this study is to describe a new species of Afrosyrphus, to document the first records of Afrosyrphus from Uganda and to provide an identification key for this genus, as well as DNA barcodes (Hebert et al. 2003a, 2003b) for the two known species of Afrosyrphus. We also review the existing literature, and after the study of collection material we re-evaluate the identity of some historical records of Afrosyrphus.

\section{Material and methods}

\section{Collecting sites}

Between January $15^{\text {th }}, 2017$ and February $7^{\text {th }}, 2017$, the authors of the present study carried out field work in the Taita Hills (Kenya) with the aim of collecting Diptera, with special focus on flower flies (Syrphidae). We stayed at the Taita Research Station of the University of Helsinki in Wundanyi (Toivonen et al. 2012), from which we made one- or two-day trips to different areas in the vicinity, including Wesu and Vuria Peaks, Mwatate area, Iyale (Fig. 1A), Chawia and Ngangao Forests.

A similar team of syrphidologists, including most of the authors of the present study, visited Uganda from December $1^{\text {st }}$ to December $18^{\text {th }}, 2018$. This time, the coordinators of the expedition were Kurt Jordaens (Royal Museum for Central Africa, Tervuren, Belgium) and James Peter Egonyu (Makerere University, Kampala, Uganda). During our stay we visited several protected areas, i.e., Ruwenzori National Park, Kibale Forest National Park, Bwindi Impenetrable National Park (Fig. 1B) and Mabamba Swamps.

In both countries, hand nets and Malaise traps were used to collect flower flies. Nevertheless, no specimens of Afrosyrphus were found among the material collected using Malaise traps.

During our study, specimens of Afrosyrphus originally collected and reared by Schmutterer (1974) were found among the material loaned to Pavel Láska in the Department of Zoology, Palacký University (Olomouc, Czech Republic). Láska and coauthors used this material to describe the puparia of some 
Betasyrphus Matsumura, 1917 (Mazánek et al. 1999) and the puparium of Afrosyrphus (Láska et al. 2000). This material was available for our study thanks to Libor Mazánek.

\section{Terminology, measurements and photography}

The new species is described in full, with terminology following Thompson (1999) and Cumming \& Wood (2017). The abbreviations used for collections follow the standard in Systema Dipterorum (Thompson 2019), and their equivalents are given below:

$\mathrm{AMNH}=$ American Museum of Natural History, New York, USA

ASPC = Axel Ssymank personal collection, Wachtberg, Germany

$\mathrm{CNC}=$ Canadian National Collection of Insects, Arachnids and Nematodes, Ottawa, Canada

ICIPE = International Centre of Insect Physiology and Ecology, Nairobi, Kenya

$\mathrm{MZH}=$ Finnish Museum of Natural History Luomus, Helsinki, Finland

$\mathrm{NBC}=$ Naturalis Biodiversity Centre, Leiden, the Netherlands

NMK = National Museum of Kenya, Nairobi, Kenya

RMCA = Royal Museum for Central Africa, Tervuren, Belgium

USNM = National Museum of Natural History, Washington DC, USA

ZFMK = Zoologisches Forschungsmuseum Alexander Koenig, Bonn, Germany

We follow the principles of FAIR \& Open Science publishing to cite the studied material as recommended by this journal. At the end of each record the holding institution is indicated.

All measurements are in millimetres and were taken using a reticule in a Leica ${ }^{\circledR} \mathrm{M} 165 \mathrm{C}$ microscope. Body length was measured from the anterior oral margin to the posterior end of the abdomen, in lateral
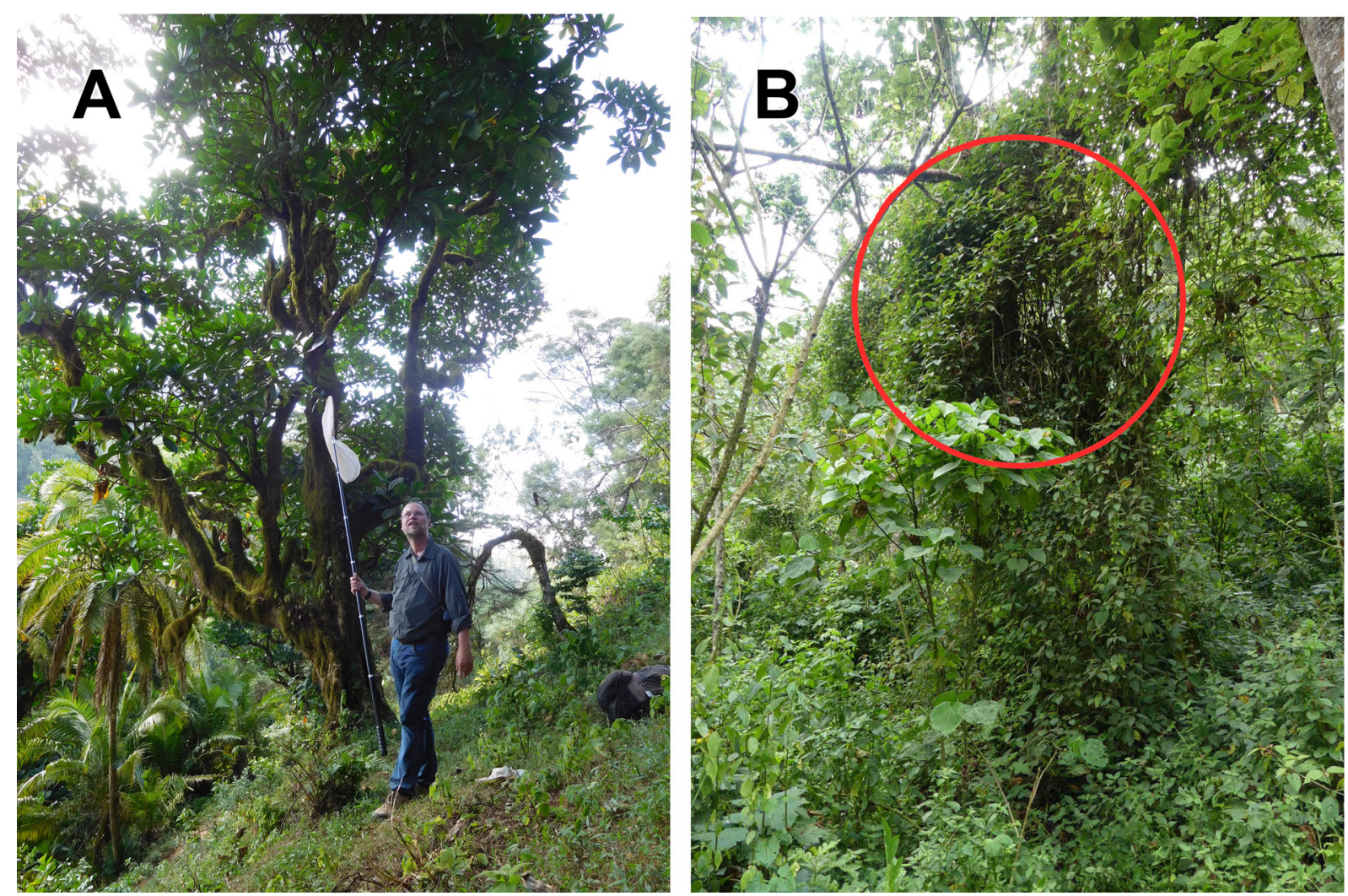

Fig. 1. Localities where Afrosyrphus schmuttereri sp. nov. was collected. A. Sampling point in the trail to Iyale (Taita Hills, Kenya). B. Sampling point in the Ruhija Section of the Bwindi Impenetrable National Park (Uganda). Red circle indicates exactly where the flower flies were hovering. 
view. Wing length was measured from the wing tip to the basicosta. Photographs were composed using Zerene Stacker ${ }^{\circledR}$ ver. 1.04 software (Richland, WA, USA), based on images of pinned specimens taken with a Canon EOS 7D ${ }^{\circledR}$ mounted on a P-51 Cam-Lift (Dun Inc., VA, USA) and with the help of Adobe Lightroom ${ }^{\circledR}$ ver. 5.6. Simple-Mappr (Shorthouse 2010) was used to create Fig. 2.

\section{Adult identification}

Existing available keys were used to identify the collected specimens. Curran (1927), Hull (1949) and Vockeroth (1969) were used to determine the genus; then, the specimens from Taita Hills were checked by direct comparison against material from several collections, including the holotype of $A$. varipes, and against the original description of $A$. varipes.

\section{Molecular studies}

One or two legs of several specimens were used for DNA extraction. Extractions were carried out using the DNeasy Blood and Tissue Kit (Qiagen Inc., Santa Clara, CA, USA) following the manufacturer's protocol. Entire specimens or remnants of specimens were preserved and labelled as DNA voucher specimens for the purpose of morphological studies and deposited in the above-mentioned collections, as listed in the 'Material examined' sections.

The mtDNA barcode of the $5^{\prime}$ region of the cytochrome $c$ oxidase subunit I gene (COI) was amplified using forward primer LCO1-1490 (5'-GCTCAACAAATCATAAAGATATTGG-3'; Folmer et al. 1994) and reverse primer COI-Dipt-2183R, also known as COI-780R (5'-CCAAAAAATCARAATARRTGYTG-3'; Gibson et al. 2011). PCR amplification protocols were the same as described in Rozo-Lopez \& Mengual (2015). All new sequences were submitted to GenBank via BOLD (www.boldsystems.org). GenBank accession numbers are listed for each sequenced specimen in the text.

We ran a distance-based Neighbor-Joining analysis using the Jukes-Cantor Model as implemented in Geneious ver. 7.1.3, where we included several DNA barcode sequences for species of the genera Epistrophe and Epistrophella Dušek \& Láska, 1967 in order to visualize the distance between the two species of Afrosyrphus. We also ran a maximum likelihood (ML) analysis using Garli ver. 2.01 (Zwickl 2006, 2011) and the GTR $+\mathrm{I}+\mathrm{G}$ model (Fig. 6). Forty-eight independent runs were conducted using scorethreshforterm $=0.05$ and significanttopochange $=0.0001$ settings and the automated stopping criterion, terminating the search when the $\mathrm{ln}$ score remained constant for 50000 consecutive generations. The tree with the highest likelihood was retained and is presented here (Fig. 6). Bootstrap support values (BS) were estimated from 1000 replicates using the same model in Garli. Analytical runs were performed on the CIPRES Science Gateway (Miller et al. 2010). All trees were drawn with the aid of FigTree ver. 1.3.1 (Rambaut 2009).

\section{Results}

Taxonomy

Phylum Arthropoda Latreille, 1829

Class Insecta Linnaeus, 1758

Order Diptera Linnaeus, 1758

Family Syrphidae Latreille, 1802

Subfamily Syrphinae Newman, 1834

Afrosyrphus Curran, 1927

\section{Type species}

Afrosyrphus varipes Curran, 1927, by monotypy. 
Differential diagnosis (adapted from Vockeroth 1969)

Moderately robust, rather pilose species with extremely long, slender antennae, obscure abdominal markings and densely pilose hind legs. Face almost straight in profile, with low tubercle, densely pale pruinose laterally, with a shining, broad, dark median facial vitta. Eye apparently bare (with extremely short and scattered pile), holoptic in male. Antenna porrect or nearly so, with postpedicel longer than scape and pedicel together; arista bare, subbasal. Mesonotum dull, heavily pruinose; pleura dull, pruinose. Thoracic pile pale, unusually long but not obscuring ground colour. Subscutellar fringe very long and dense. Dorsal and ventral katepisternal pile patches narrowly joined posteriorly, clearly separated anteriorly. Metasternum bare. Hind coxa and hind trochanter with a pile tuft at median angle. Wing membrane with extensive bare areas on rather more than basal half, microtrichia on rest of membrane very fine but moderately dense. Ventral calypter with many fine, erect pale pile on posterior part of dorsal surface. Apical half of hind femur and hind tibia of both sexes with dense dorsal and ventral fringes of long, mostly dark pile. Abdomen unmargined, narrowly oval, long pilose.

\section{Distribution}

Afrotropical Region (see Fig. 2).

\section{Systematic remarks}

Vockeroth (1969) suggested a close relationship with Epistrophe based on adult morphology and male genitalia. Láska et al. (2000) described the puparium of Afrosyrphus based on the material from Kenya collected by Schmutterer and argued that Afrosyrphus is more closely related to Epistrophella based on the puparium morphology. Our unpublished target enrichment Syrphinae phylogeny supports both of these hypotheses, with Epistrophella sister to Afrosyrphus + Epistrophe.

Afrosyrphus schmuttereri sp. nov. urn:1sid:zoobank.org:act:974F2588-579F-44AA-940C-F2FB9390B195

Figs $1-2,3 B, 3 D, 4 B-C, 5 B, 5 F-H, 6$

Afrosyrphus varipes - Schmutterer 1972a: 447; 1972b: 279; 1974:44. — Láska et al. 2000: 79.

\section{Differential diagnosis}

This species can be distinguished from $A$. varipes as stated in the identification key. Overall a more robust species with slightly broader abdomen, darker pilosity in calypter, scutum and abdominal segments, and male frontal triangle with black pruinosity along eye margin that looks entirely shiny (Fig. 3B-C). Male

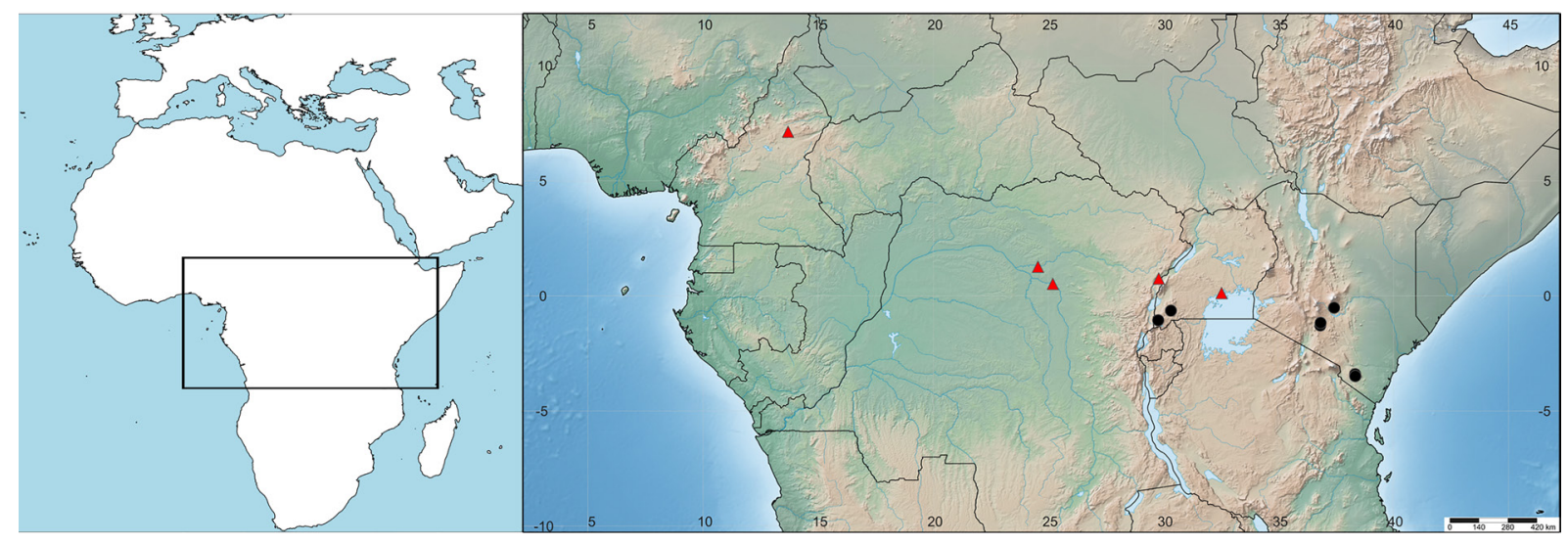

Fig. 2. Known distribution of Afrosyrphus varipes Curran, 1927 (red triangles) and Afrosyrphus schmuttereri sp. nov. (black circles). 
genitalia as in Fig. 5F-H. Females are also darker than in A. varipes. In females, tergite 2 has a posterior dark fascia (tergite 2 entirely orange in A. varipes; Fig. 4A-B), the femora are darker than the tibiae (femora only slightly darker than tibiae in $A$. varipes) and the face is dark in background colour (orange in $A$. varipes). Both sexes have similar hind legs. The hind first tarsomere (= metabasitarsomere) appears orange and shining, as it has no long, black pile (Fig. 5B).

\section{Etymology}

This new species is named after its first collector, Prof. Heinrich Schmutterer, in his honour, for his dedicated work on entomology in Kenya. This species epithet is to be treated as a noun in the genitive case.

\section{Material examined}

\section{Holotype}

KENYA - ơ; Nairobi Province, Nairobi City, Chimoro; 01¹6.502' S, 36²48.452' E; 1686 m a.s.l. [approx. altitude]; 3 Oct. 1970; H. Schmutterer leg.; specimen identifier: ZFMK-DIP-00067253; ZFMK.

\section{Paratypes}

KENYA • 1 \% ; same collection data as for holotype; specimen identifier: ZFMK-DIP-00067254; ZFMK •

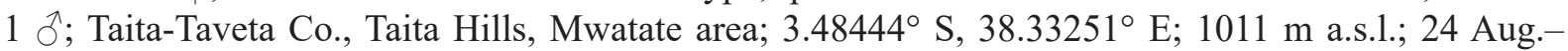
7 Sep. 2011; R. Copeland leg.; Malaise trap below Bura Bluff, riverine forest; specimen identifier: ICIPE 9542; ICIPE • 3 o $^{\top}$; Taita Taveta Co., Taita Hills, trail to Iyale; $3.40094^{\circ} \mathrm{S}, 38.33206^{\circ} \mathrm{E} ; 1867 \mathrm{~m}$ a.s.l.; 27 Jan. 2017; A. Ssymank leg.; ASPC • 2 ô; same collection data as for preceding; G. Ståhls leg.; specimen identifiers: https://id.luomus.fi/GJ.1956, https://id.luomus.fi/GJ.1957; GenBank: MN662559, MN662545; MZH - 6 ô; ; same collection data as for preceding; 28 Jan. 2017; X. Mengual leg.; specimen identifiers: ZFMK-DIP-00019820, 00019826, 00019828 to 00019829, 00019831, 00015961; ZFMK・ 2 ふぇ; same collection data as for preceding; specimen identifers: ZFMK-DIP-19822 to 19823; NMK • 5 ô; same collection data as for preceding; M. Reemer leg.; NBC • 1 ô; same collection data

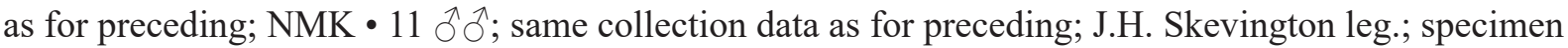
identifiers: CNC657049 to 657051 , CNC653515 to 653522; CNC • 2 ô. for preceding; specimen identifiers: CNC653523 to 653524; NHK -1 ' ; same collection data as for preceding; specimen identifier: CNC653525; USNM • 3 万人 ; same collection data as for preceding; 1 Feb. 2017; X. Mengual leg.; specimen identifiers: ZFMK-DIP-00019825, 00019827, 00015960; ZFMK• 1 T ; same collection data as for preceding; specimen identifier: ZFMK-DIP-00015967; alternative specimen identifier: CNC1565136; GenBank: MN662563; ZFMK • 1 क; Eastern Province, Njuki-ini Forest, near forest station; $0.51660^{\circ} \mathrm{S}, 37.41843^{\circ} \mathrm{E} ; 1455 \mathrm{~m}$ a.s.1.; 14-28 Aug. 2007; R. Copeland leg.; Malaise trap, inside indigenous forest; specimen identifier: USNM ENT 01518184; USNM.

UGANDA • 1 q; Western Region, Ankole District; 30 Dec. 1975; M. Paulus leg.; specimen identifier: CNC DIPTERA 102961; GenBank: MN662536; CNC • 6 ô के; Western Region, Kabale District, Bwindi Impenetrable National Park, Ruhija Section; $1.06114^{\circ}$ S, $29.77811^{\circ}$ E; 2314 m a.s.1.; 14 Dec. 2018; M. Reemer leg.; $\mathrm{NBC} \bullet 1$ क; same collection data as for preceding; $\mathrm{CNC} \bullet 1$; ; same collection data as for preceding; MZH $\bullet 1$; same collection data as for preceding; RMCA $\bullet 1$; same collection data as for preceding; specimen identifier: ZFMK-DIP-00061259; GenBank: MN662534; ZFMK.

\section{Description}

\section{Male}

HEAD (Figs 3D, 4C). Face with distinct, low facial tubercle and with 3-4 grooves, black medially and yellow laterally, yellow pilose with seldom black pile on dorsal half and a shiny, bare median vitta, with dense pale pruinosity covering yellow lateral areas; gena yellow, with a small black macula at eye 
margin, yellow pilose with pale pruinosity dorsally; lunule black, with violet iridescence; frons black, with long black pile, shiny medially, with black pruinosity along eye margin (following pale pruinosity of face) and dorsally at eye angle; vertical triangle black, black pruinose, black pilose; antennal base inflated, protruded; antennal pits clearly separated; antenna elongated, black pilose, scape partly brown, pedicel and postpedicel black; postpedicel longer than scape and pedicel together; arista black, bare; eye almost bare, with a few scattered pile; occiput pale pruinose.
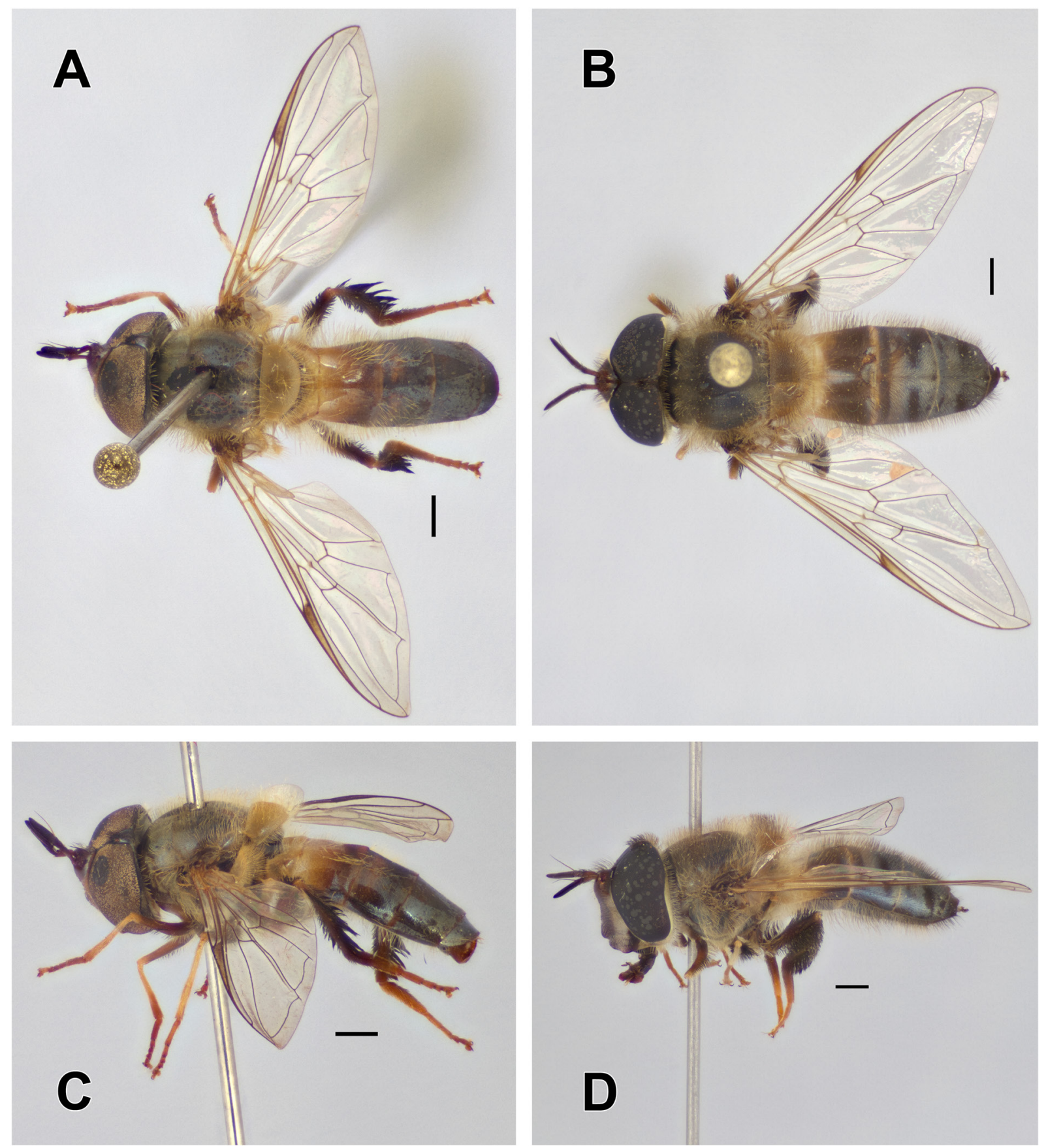

Fig. 3. A. Afrosyrphus varipes Curran, 1927, ठ̊ (ZFMK-DIP-00015968), dorsal view. B. Afrosyrphus schmuttereri sp. nov., paratype, § (ZFMK-DIP-00019829), dorsal view. C. Afrosyrphus varipes, § (ZFMK-DIP-00015968), lateral view. D. Afrosyrphus schmuttereri sp. nov., paratype, ô (ZFMKDIP-00019829), lateral view. Scale bars: $1 \mathrm{~mm}$. 
Thorax (Fig. 4B-C). Scutum black, densely pale pruinose, with long yellow and brown pile; postpronotum paler, bare, densely pale pruinose; postalar callus yellow; scutellum yellow, pale pruinose, mostly dark pilose with some pale pile on anterior and posterior margins, subscutellar fringe with long, yellow pile. Pleuron black except katatergum yellow, densely pale pruinose, yellow pilose; metaepisternum bare; metasternum bare; postmetacoxal bridge incomplete; calypter yellow, mostly yellow pilose, ventral calypter with brown fringe and fine erect pile on posterior part of dorsal surface; plumule long, pale; halter pedicel and capitulum yellow; posterior spiracular fringes yellow.
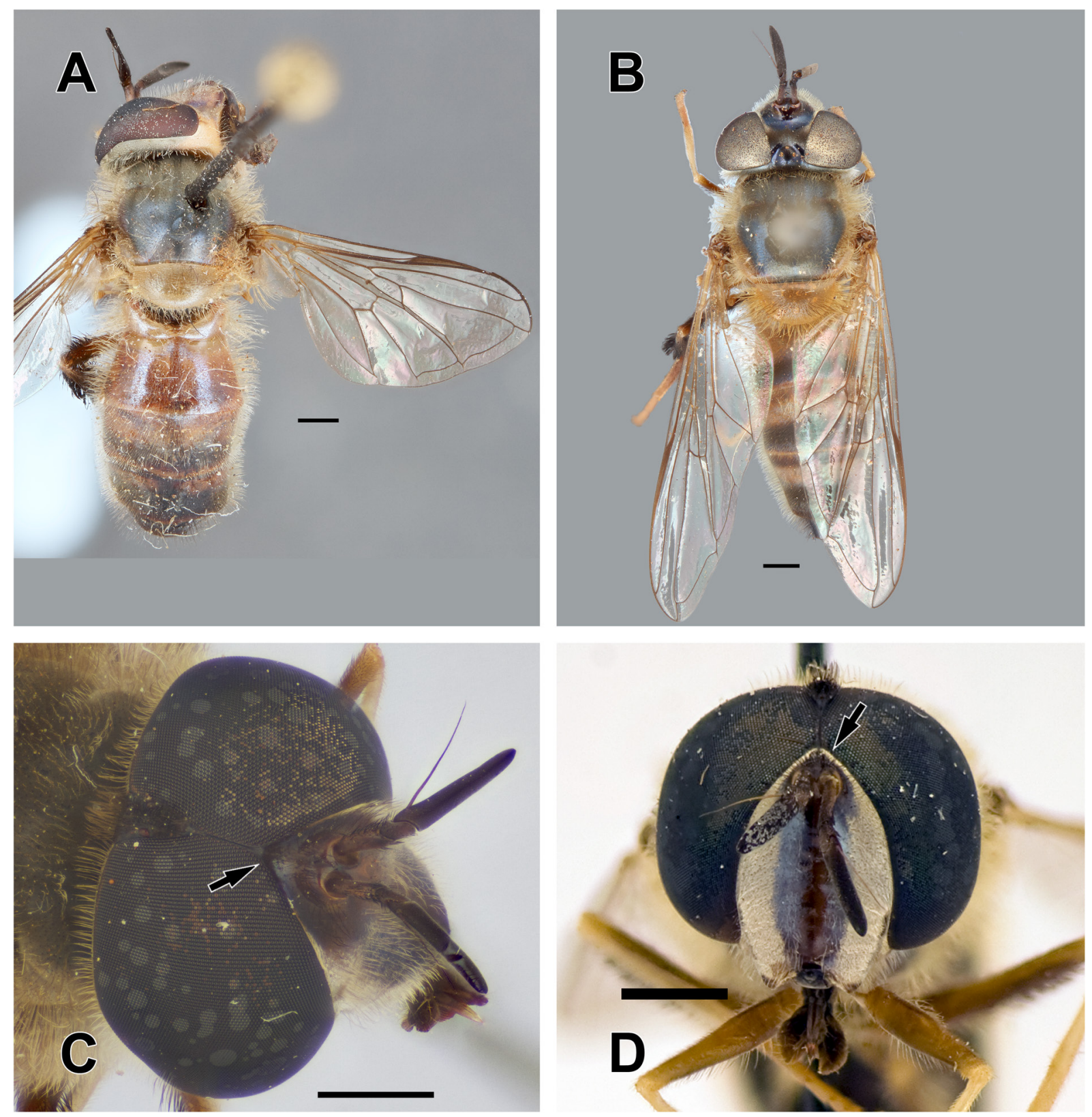

Fig. 4. A. Afrosyrphus varipes Curran, 1927, $q$ (CNC DIPTERA 102962), dorsal view. B. Afrosyrphus schmuttereri sp. nov., paratype, $q$ (CNC DIPTERA 102961), dorsal view. C. Afrosyrphus schmuttereri

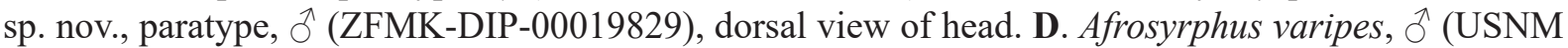
ENT 00114576), frontal view of head. Arrows on C and D indicate the frontal triangle. Scale bars: $1 \mathrm{~mm}$. 
WING. Hyaline, stigma yellow except dark brown basally; membrane bare basally, cells c, br and bm entirely bare, apical cells microtrichose but bare very basally; alula microtrichose.

LEGS. Coxae and trochanters black, mostly yellow pilose; fore and mid femur yellow at base very narrowly and on apical half, darker basally; fore femur with long pile posteriorly, black apically and yellow basally; mid femur similar, but also with long pile anteriorly; fore and mid tibia yellow, yellow pilose; fore and mid tarsomeres yellow; hind coxa and hind trochanter with tuft of black pile medially; hind femur and hind tibia brown; hind femur with dense dorsal and ventral fringes of long pile, yellow on basal half and black on apical half; hind tibia with dense dorsal and ventral fringes of long black pile; hind tarsomeres pale.

AвDOMEn (Fig. 4B-C). Unmargined, narrowly oval, long pilose. Tergite 1 yellow, densely pale pruinose, yellow pilose; tergite 2 yellow on basal half and posterior margin, black on posterior half, with posterior margin yellow, pale pilose anteriorly and laterally, dark pilose medially on posterior half, densely pale pruinose; tergite 3 yellow on basal half, black on posterior half and on lateral margins, yellow pilose laterally and dark pilose medially, with some pale pile on anterior margin, densely pale pruinose, with two fasciate areas on posterior half less pruinose; tergite 4 black with a yellow fascia on posterior margin, with two medial yellow maculae on anterior half, yellow pilose laterally and dark pilose medially, densely pale pruinose, with two fasciate areas on posterior half less pruinose, smaller than on tergite 3; tergite 5 black, pruinose, black pilose. Sternite 1 yellow, with long yellow pile; sternites 2 and 3 yellow anteriorly and black posteriorly, with long yellow and black pile; sternite 4 black, long black pilose.

Male Genitalia. As in Fig. 5F-H.

\section{Female}

Similar to male except normal sexual dimorphism and as specified in diagnosis.

\section{Variation}

Based on studied material, colouration of pile on scutum and scutellum may vary slightly in amount of dark pile, ranging from little to many.

Length $(\mathrm{N}=4)$ : body $12.7 \mathrm{~mm}(12.5-12.8 \mathrm{~mm})$; wing $10.9 \mathrm{~mm}(10.8-11.0 \mathrm{~mm})$.

\section{Genetics}

A total of five specimens was successfully sequenced; three 5 '-COI sequences with a length of $658 \mathrm{bp}$ (https://id.luomus.fi/GJ.1957,Genbank:MN662545; https://id.luomus.fi/GJ.1956,Genbank:MN662559; ZFMK-DIP-00061259; Genbank: MN662534), one 627 bp long (ZFMK-DIP-00015967, Genbank: MN662563) and one sequence that was 307 bp long (CNC DIPTERA 102961, Genbank: MN662536). The obtained DNA barcodes have an uncorrected pairwise distance of $0.08-1.52 \%$ among the specimens of this new species and differ by $5.54-6.54 \%$ from the two COI sequences obtained for $A$. varipes.

\section{Biology}

Schmutterer used larvae of Afrosyrphus to study their biological response as predators of common aphid species in East Africa (Schmutterer 1972b) or as prey for East African ants (Schmutterer 1972a). Schmutterer (1974) reared larvae of Afrosyrphus feeding on several hosts on six species of plants belonging to five different families from Kenya (preys and host plants are summarized in Table 1). $\mathrm{He}$ wrote that larvae of Afrosyrphus "of older stages of development stand out in comparison to those of many other aphidophagous Syrphidae of East Africa by their relatively broad, strongly flattened body. The greenish yellow of the last larval stage turns brownish 2-3 days before pupation. The drop-shaped, brown pupa has at its rear end a relatively long extension formed from a pair of stigmatic tubes." 

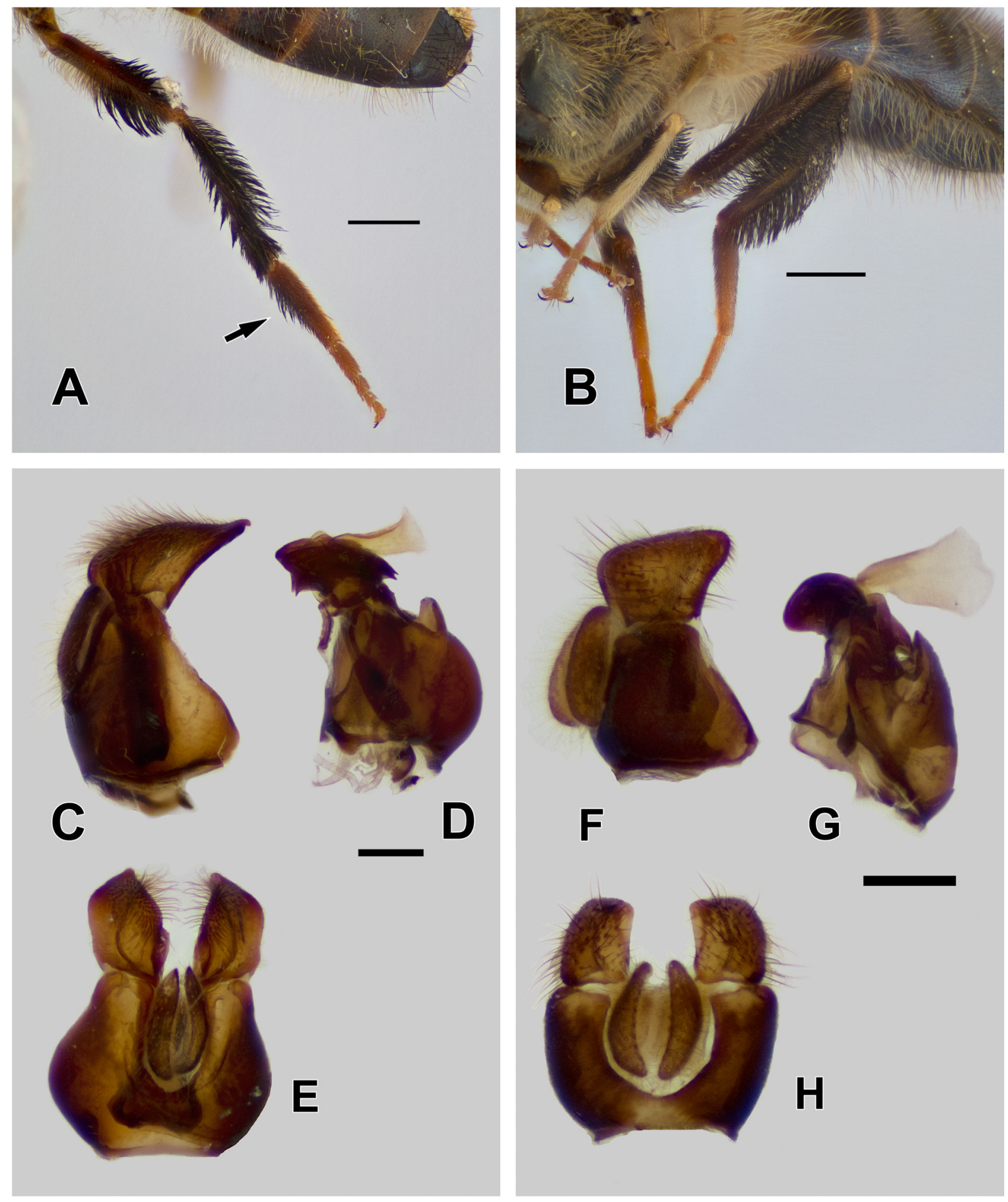

Fig. 5. A. Afrosyrphus varipes Curran, 1927, $q$ (ZFMK-DIP-00015969), hind leg. Arrow indicates the long black pile on the hind first tarsomere (= metabasitarsomere). B. Afrosyrphus schmuttereri sp. nov., paratype, ô (ZFMK-DIP-00019829), hind leg. C-E. Afrosyrphus varipes, ठิ (ZFMK-DIP-00015968), genitalia. C. Epandrium and surstyli, lateral view. D. Hypandrium, postgonites and aedeagus, lateral view. E. Epandrium, cerci and surstyli, dorsal view. F-H. Afrosyrphus schmuttereri sp. nov., paratype, $\widehat{\sigma}$ (ZFMK-DIP-00019829), genitalia. F. Epandrium and surstyli, lateral view. G. Hypandrium, postgonites and aedeagus, lateral view. H. Epandrium, cerci and surstyli, dorsal view. Scale bars: $A-B=1 \mathrm{~mm}$; $\mathrm{C}-\mathrm{H}=0.25 \mathrm{~mm}$. 
Table 1. Reported prey, host plants and localities for Afrosyrphus schmuttereri sp. nov. in Kenya (adapted from Schmutterer 1974). Hemipteran names follow Favret (2019) and plant names follow The Plant List (2013).

\begin{tabular}{ccc}
\hline Prey (Aphidoidea) & Host plant & Locality and dates \\
\hline $\begin{array}{c}\text { Brachycaudus aegyptiacus } \\
\text { (Hall, 1926) }\end{array}$ & $\begin{array}{c}\text { Rumex abyssinicus Jacq. } \\
\text { (Polygonacea) }\end{array}$ & $\begin{array}{c}\text { Nairobi Co., Chiromo: 11 Sep. 1970, } \\
\text { 3 Oct. 1970, 16 Nov. 1970 }\end{array}$ \\
\hline $\begin{array}{c}\text { Brevicoryne brassicae } \\
\text { (Linnaeus, 1758) }\end{array}$ & $\begin{array}{c}\text { Brassica oleracea } \text { L. } \\
\text { (Brassicaceae) }\end{array}$ & $\begin{array}{c}\text { Taita-Taveta Co., Taita Hills: 16 Nov. 1970; } \\
\text { Nairobi Co., Chiromo: 5 Sep. 1970 }\end{array}$ \\
\hline $\begin{array}{c}\text { Uroleucon compositae } \\
\text { (Theobald, 1915) }\end{array}$ & $\begin{array}{c}\text { Baccharoides lasiopus } \\
\text { (O.Hoffm.) H.Rob. } \\
\text { (Asteraceae) }\end{array}$ & $\begin{array}{c}\text { Kiambu Co., Upper Kiambu: 30 Jan. 1970; Nairobi } \\
\text { Co., Chiromo: 14 Jul. 1970, 28 Aug. 1970, 3 Oct. } \\
\text { 1970, 22 Oct. 1970, 14 Dec. 1970, 22 Jan. 1971 }\end{array}$ \\
\hline $\begin{array}{c}\text { Hyperomyzus lactucae } \\
\text { (Linnaeus, 1758) }\end{array}$ & $\begin{array}{c}\text { Sonchus oleraceus (L.) L. } \\
\text { (Asteraceae) }\end{array}$ & Nairobi Co., Chiromo: 24 Oct. 1970 \\
\hline $\begin{array}{c}\text { Macrosiphum rosae } \\
\text { (Linnaeus, 1758) }\end{array}$ & Rosa sp. (Rosaceae) & Nairobi Co., Convent Drive: \\
\hline $\begin{array}{c}\text { Myzus persicae } \\
\text { (Sulzer, 1776) }\end{array}$ & $\begin{array}{c}\text { Solanum seaforthianum } \\
\text { Andrews (Solanaceae) }\end{array}$ & Nairobi Co., Chiromo: 19 Jan. 1971 \\
\hline
\end{tabular}

Schmutterer (1974) also stated that "in laboratory experiments, mature larvae ready to pupate are quiescent under certain conditions and can survive several weeks without damage". He noted that at constant temperature, low humidity causes the quiescence, and guessed that Afrosyrphus spans longer periods of drought as a quiescent larva under field conditions. This could be the reason why adults almost disappear in the highlands of Kenya during dry seasons (Schmutterer 1974).

Ssymank (2012) collected four adult specimens of $A$. varipes between 10:00 and 12:00 at full sun on a hilltop with a single flowering tree, Phyllanthus discoideus (Baill.) Müll.Arg. (Euphorbiaceae). However, specimens of the new species from Taita Hills were collected between 10:00 and 11:00, hovering high between large trees in the shade. These specimens were all males and clearly using the opening between the trees on the slope as a landmark while waiting for females to appear. This landmark mating strategy is common in syrphids and similar to hilltopping, but the flies may use any type of landmark from a trail to a forest opening, rocks or a particular tree (Skevington 2008). The trees in the shade were close to the forest margin of a primary lower montane cloud forest (Fig. 1A), in a small valley invaded by the South American invasive angel's trumpet of the family Solanaceae, Brugmansia suaveolens (Humb. \& Bonpl. ex Willd.) Bercht. \& J.Presl. Schmutterer (1974) reported larvae of Afrosyrphus feeding on the aphid Myzus persicae (Sulzer, 1776) from the closely related invasive Solanum seaforthianum Andrews; thus, B. suaveolens might be the host plant of the aphids for the Afrosyrphus larvae in the Taita Hills area.

Regarding the specimens collected from Bwindi Impenetrable National Park (Uganda), they were collected between 10:00 and 11:00, hovering in a sunspot in dense, moist forest over the top of a small tree approximately $3 \mathrm{~m}$ high, at heights of between 3 and $6 \mathrm{~m}$ (Fig. 1B). Once the area fell into shade, no more specimens could be found.

The type locality is in Nairobi City, probably the urban park and Nairobi riverside in or near Chiromo. According to the host plants in Table 1 reported by Schmutterer (1974), the vegetation and habitat is ruderal, with tall herb vegetation on deep soils probably adjacent to the Nairobi River. The larvae obviously use different aphid species on a variety of plant families, including aphids living on up to $4 \mathrm{~m}$ tall herbs like the spinach rhubarb (Rumex abyssinicus Jacq.) and the invasive Brazilian nightshade (Solanum seaforthianum). Some humidity may play an important role in supporting good aphid populations and the larval development of Afrosyrphus. We assume, based on our own records, that the 
primary habitat is forest margins or canopy gaps in lower montane cloud forest, where tall lush herb vegetation naturally grows, and that the type locality represents the secondary habitat type of the species.

\section{Distribution}

Species known from Uganda and Kenya (Fig. 2).

\section{Remarks}

The material collected and reared by Schmutterer (1972a, 1972b, 1974) was originally identified as Afrosyrphus varipes, but our study of this material revealed that it belongs to A. schmuttereri sp. nov. The puparium description by Láska et al. (2000) was based on material reared by Schmutterer (1974); thus, Láska et al. (2000) described the puparium of A. schmuttereri sp. nov. Moreover, Láska et al. (2000) stated that the immature stages the authors used to describe the puparium of Afrosyrphus were collected on 30 Oct. 1970 by Prof. Schmutterer from colonies of the aphid Brachycaudus aegyptiacus (Hall, 1926) in Nairobi. After study of all the published works by Schmutterer (1972a, 1972b, 1974), we think that Láska et al. (2000) were referring to the material from Chiromo (Nairobi) collected on 3 Oct. 1970, as no other immature specimens were collected in October 1970 in Nairobi on B. aegyptiacus. Reared adults from those immatures collected on 3 Oct. 1970 belong to the type series of $A$. schmuttereri sp. nov., i.e., the holotype male (ZFMK-DIP-00067253) and a paratype female (ZFMK-DIP-00067254).

Afrosyrphus varipes Curran, 1927

Figs 1-2, 3A, C, 4A, D, 5A, C-E, 6

Afrosyrphus varipes Curran, 1927: 50 (type locality: Kisangani [=Stanleyville], Democratic Republic of the Congo; holotype, ô, AMNH, by monotypy).

\section{Differential diagnosis}

This species can be distinguished from A. schmuttereri sp. nov. as stated in the identification key. Overall a smaller species with slightly narrower abdomen, paler pilosity on calypter fringe, scutum and abdominal segments, and male frontal triangle with pale pruinosity along eye margin (Fig. 4D). Male genitalia as in Fig. 5C-E, with ventrally pointed surstyli and postgonites with a large triangular posterodorsal process (see also Vockeroth 1969: fig. 29). Females are also lighter than in A. schmuttereri sp. nov. Tergite 2 is entirely orange in A. varipes (with posterior black fascia in A. schmuttereri sp. nov.), the femora are only slightly darker than the tibiae (femora darker than tibiae in A. schmuttereri sp. nov.), and the face is pale in background colour (black in A. schmuttereri sp. nov.). Both sexes have similar hind legs. The hind first tarsomere (= metabasitarsomere) appears dark and bristly due to the presence of long, black pile (Fig. 5A).

\section{Material examined}

\section{Holotype}

DEMOCRATIC REPUBLIC OF THE CONGO • ${ }^{\wedge}$; Tshopo Province, Kisangani [= Stanleyville]; $1^{\circ} \mathrm{N}$, 25.1667 E; ca $460 \mathrm{~m}$ a.s.l.; Mar. 1915; Lang and Chapin leg.; based on image at http://research.amnh. org/iz/types_db/details.php?specimen_id=2410; AMNH.

\section{Other material}

CAMEROON • 1 § , 2 क 9 ; Adamaoua Province, Ngaoundéré, Ranch de Ngaoundaba; $7.12944^{\circ} \mathrm{N}$, 13.69556 E E; 1265 m a.s.l.; 12 May 2006; A. Ssymank leg.; specimen identifiers: ZFMK-DIP-00015968 to 00015970; ASPC - 1 क; same collection data as for preceding; specimen identifier: ZFMKDIP-00015971; GenBank: MN662551; ZFMK.

DEMOCRATIC REPUBLIC OF THE CONGO • 1 j ; Tshopo Province, Yambuya; $1.263669^{\circ} \mathrm{N}$, $24.552813^{\circ} \mathrm{E}$; ca $400 \mathrm{~m}$ a.s.1.; 24 Nov. 1913; J. Bequaert leg.; specimen identifier: USNM ENT 
00114576; USNM • 1 § ; North Kivu Province, P.N. Albert, Lesse (near Tungudu); $0.75^{\circ}$ N, $29.8^{\circ}$ E; 760 m a.s.1.; 21 Jul. 1914; J. Bequaert leg.; specimen identifier: RMCA ENT 000034062; RMCA.

UGANDA • 1 क; Central Region, Entebbe, Kisubi Forest; $0.11928^{\circ}$ N, $32.52831^{\circ}$ E; ca $1160 \mathrm{~m}$ a.s.1.; 24 Apr. 1976; M. Paulus leg.; specimen identifier: CNC DIPTERA 102962; GenBank: MN662560; CNC.

\section{Genetics}

A total of two specimens was successfully sequenced, one sequence with a length of 627 bp (ZFMKDIP-0001597, Genbank: MN662551) and another one 307 bp long (CNC DIPTERA 102962, Genbank: MN662560). The obtained COI sequences have an uncorrected pairwise distance of $0.33 \%$ and differ by 5.54-6.54\% from the COI sequences obtained for A. schmuttereri sp. nov.

\section{Distribution}

This species has previously been recorded from Cameroon (Ssymank 2012), DRC (Curran 1927, 1938b), Angola and South Africa (Smith \& Vockeroth 1980) (see also Dirickx 1998). No specimens from the latter two countries were studied by the present authors, as Smith \& Vockeroth (1980) did not provide any information about the records. Here, we present the first records from Uganda. The material from Kenya collected and studied by Schmutterer (1974) was originally identified as A. varipes, but it belongs to $A$. schmuttereri sp. nov. Consequently, the presence of $A$. varipes in Kenya needs confirmation, as well as its presence in Angola and South Africa.

\section{MtDNA COI barcodes}

The topology of the tree with the highest likelihood (Fig. 6) compared favourably with the NeighborJoining tree (not shown). A total of seven specimens were successfully sequenced. The obtained COI sequences have an uncorrected pairwise distance of $0.08-1.52 \%$ among the specimens of $A$. schmutterer $i$ sp. nov., $0.33 \%$ between the two specimens of $A$. varipes and $5.54-6.54 \%$ between the two species of Afrosyrphus.

\section{Key to species of Afrosyrphus Curran, 1927}

1. Females: eyes separated above antennae (dichoptic) (Fig. 4B) .... 3

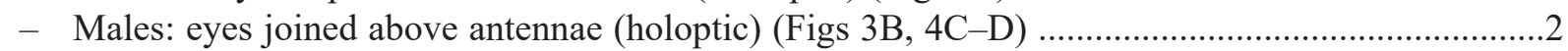

2. Hind first tarsomere without long, black pile (Fig. 5B). Abdominal tergites 2-4 dark pilose medially and pale pilose laterally, except tergites 2 and 3 pale pilose on anterior margin; tergite 5 dull, pruinose (Fig. 3B, D). Scutellum mostly dark pilose, with some pale pile on anterior and posterior margins (Fig. 3B, D). Ventral calypter fringe with dark pile. Frontal triangle shiny medially, with black pruinosity along eye margin and dorsally ( appearing entirely shiny, black; Fig. 4C). Genitalia as in Fig. 5F-H (Kenya, Uganda) .................................... s. schmuttereri sp. nov.

- Hind first tarsomere with long, black pile on basal 1/3 (Fig. 5A). Abdominal tergites 2-4 entirely pale pilose; tergite 5 shiny (Fig. 3A, C). Scutellum mostly pale pilose, with seldom dark pile (Fig. $3 \mathrm{~A}, \mathrm{C})$. Ventral calypter fringe with pale pile. Frontal triangle shiny medially, with pale pruinosity along eye margin (Fig. 4D). Genitalia as in Fig. 5C-E (Cameroon, DRC, Uganda, Angola?, South Africa?)

A. varipes Curran, 1927

3. Hind first tarsomere without long, black pile (Fig. 5B). Tergite 2 with black fascia on posterior margin (Fig. 4B). Face dark in background colour (Kenya, Uganda) ............ A. schmuttereri sp. nov.

- Hind first tarsomere with long, black pile on basal 1/3 (Fig. 5A). Tergite 2 entirely orange (Fig. 4A). Face paler, orange in background colour (Cameroon, DRC, Uganda, Angola?, South Africa?) A. varipes Curran, 1927 


\section{Discussion}

The African hover fly fauna remains one of the most poorly collected and studied continental faunas in the world. Finding a new species in a previously monotypic genus is a significant discovery that helps us better understand the morphological boundaries of the lineage. The description of a new species here also reassigns known ecological and larval information previously attributed to $A$. varipes. Further study on $A$. varipes is now warranted, as we can only assume that the larvae perform similar functions. Recent increased interest in the African fauna will undoubtedly turn up many other important new discoveries.

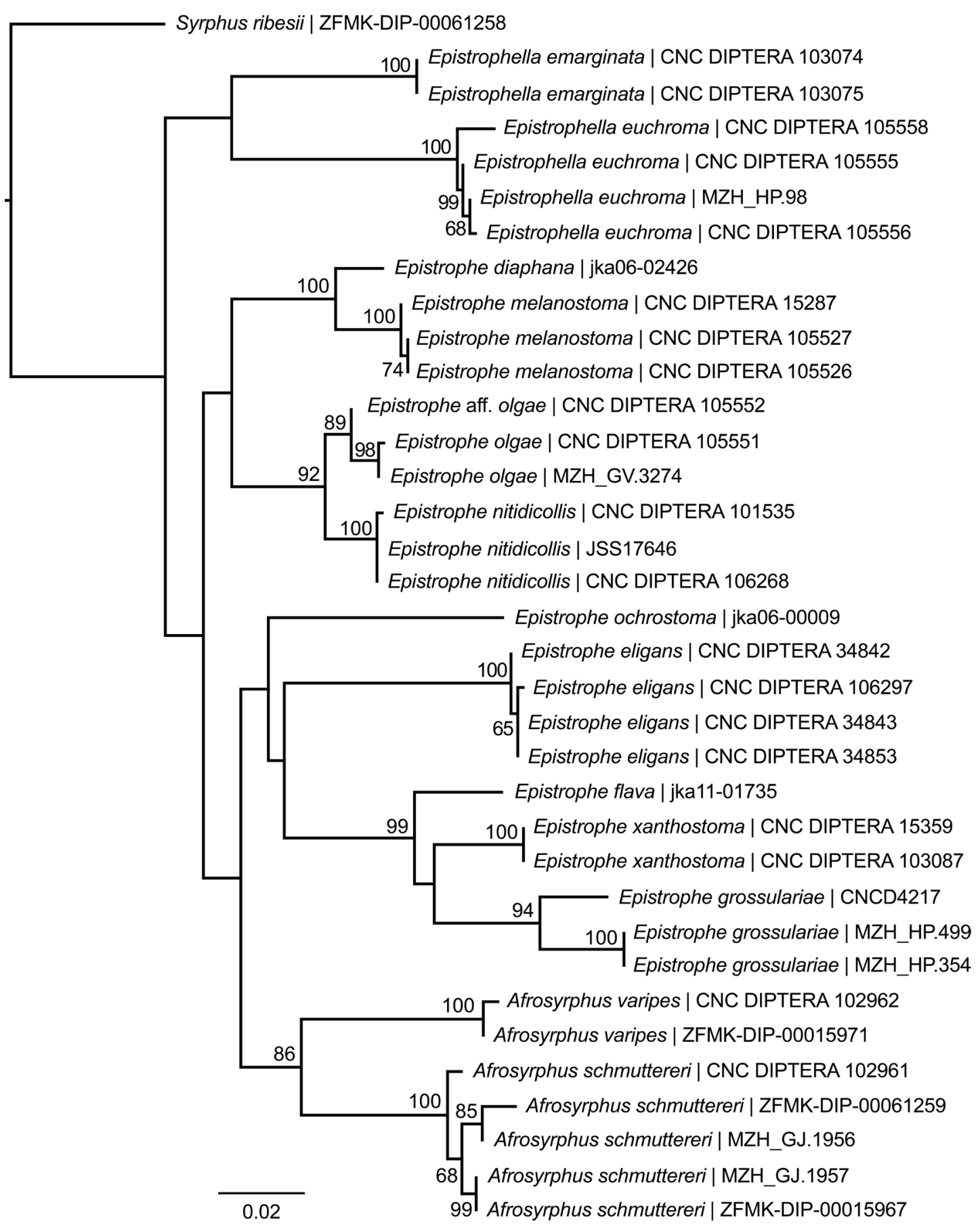

Fig. 6. Maximum-likelihood tree ( $\ln \mathrm{L}=-2626.879678)$ based on COI barcodes, using Garli ver. 2.01. Bootstrap support values are depicted at the nodes (only $>50$ ). 
From the currently known geographical distribution and altitudinal range (from ca 1011 to $2314 \mathrm{~m}$ a.s.1.) we can assume that Afrosyrphus schmuttereri sp. nov. is essentially an Eastern arc Afromontane species (in the Afromontane-Afroalpine Biotic Zone; Happold \& Lock 2013), which may potentially occur in and around all lower and higher cloud forest relics, and possibly even southwards up to the Drakensberg in South Africa, although we do not have data. Afrosyrphus varipes, on the other hand, seems to be linked to the Rainforest Biotic Zone in the western and central part of the African continent, with a much lower known altitudinal range (from 400 to $1265 \mathrm{~m}$ a.s.1.).

A serious threat to the primary habitat of Afrosyphus schmuttereri sp. nov. is the rapid loss of natural primary cloud forests in the region (Rogers et al. 2008; Wagura 2014) due to overuse of water, as well as spreading corn fields and settlements into the cloud forest areas. We believe that the spraying of pesticides may be an important threat as well, as some of the reported host plants are cultivated as edible plants or for medical use (Rumex abyssinicus Jacq. and also Baccharoides lasiopus (O.Hoffm.) H.Rob.; see Useful Tropical Plants Database 2019). Consequently, as important pollinators and flower visitors, hover flies should be protected as far as possible by the use of selective pesticides when chemical control measures are applied against homopterous insects. Nevertheless, some agricultural use and anthropogenic changes can promote secondary urban or riverine vegetation, which is obviously suitable for Afrosyrphus larvae. The loss of larger areas of the natural cloud forests will inevitably also change the water balance and reduce the available secondary habitats, as brooks and small rivers will dry out and no longer have lush herbaceous vegetation.

\section{Acknowledgements}

We thank Libor Mazánek for making available the material originally collected by Prof. Heinrich Schmutterer. We also thank Prof. Heinrich Schmutterer, Björn Rulik (ZFMK), Andrea HastenpflugVesmanis (Senckenberg Naturmuseum Frankfurt) and Frank Jauker (Justus-Liebig-University, Giessen) for tracking back the material collected in Kenya during the 1970s. We are indebted to Kurt Jordaens and James Peter Egonyu for the organization of our field trip to Uganda (permits no. NS 642 and UWA/COD/96/05) and to Laban Njoroge for the collecting and export permits in Kenya (MTA NMKInvL-2017-138). We thank Luciane Marinoni for checking the available material of Afrosyrphus at the USNM collections. We thank Bob Copeland (ICIPE) and Torsten Dikow (USNM) for sharing data and images with us for this work. We also thank Kurt Jordaens for his suggestions and helpful comments that helped to improve our original text. Funding to JHS was provided by an Agriculture and Agri-Food Canada A-base research grant. XM has received funding from the European Union's Horizon 2020 Research and Innovation Programme under Marie Sklodowska-Curie grant agreement no. 642241.

\section{References}

Cumming J.M. \& Wood D.M. 2017. Adult morphology and terminology. In: Kirk-Spriggs A.H. \& Sinclair B.J. (eds) Manual of Afrotropical Diptera, Vol. 1: 89-133. Suricata 4, South African National Biodiversity Institute, Pretoria.

Curran C.H. 1927. Diptera of the American Museum Congo Expedition. Part I. Bibionidae, Bombyliidae, Dolichopodidae, Syrphidae and Trypaneidae. Bulletin of the American Museum of Natural History 57: 33-89. Available from http://hdl.handle.net/2246/1640 [accessed 2 Apr. 2020].

Curran C.H. 1938a. Records and descriptions of African Syrphidae - I (Diptera). American Museum Novitates 1009: 1-15. Available from http://hdl.handle.net/2246/2207 [accessed 2 Apr. 2020].

Curran C.H. 1938b. Records and descriptions of African Syrphidae - II (Diptera). American Museum Novitates 1010: 1-20. Available from http://hdl.handle.net/2246/2208 [accessed 2 Apr. 2020].

Curran C.H. 1939a. Records and descriptions of African Syrphidae - III (Diptera). American Museum Novitates 1025: 1-11. Available from http://hdl.handle.net/2246/2217 [accessed 2 Apr. 2020]. 
Curran C.H. 1939b. Records and descriptions of African Syrphidae - IV (Diptera). American Museum Novitates 1026: 1-10. Available from http://hdl.handle.net/2246/2218 [accessed 2 Apr. 2020].

Dirickx H.G. 1998. Catalogue synonymique et géographique des Syrphidae (Diptera) de la région Afrotropicale. Instrumenta Biodiversitatis 2: 1-187.

Favret C. 2019. Aphid Species File. Version 5.0/5.0. Available from http://Aphid.SpeciesFile.org [accessed 20 May 2019].

Folmer O., Black M., Hoeh W., Lutz R. \& Vrijenhoek R. 1994. DNA primers for amplification of mitochondrial cytochrome $\mathrm{C}$ oxidase subunit I from metazoan invertebrates. Molecular Marine Biology and Biotechnology 3: 294-299.

Gibson J.F., Kelso S., Jackson M.D., Kits J.H., Miranda G.F.G. \& Skevington J.H. 2011. Diptera-specific polymerase chain reaction amplification primers of use in molecular phylogenetic research. Annals of the Entomological Society of America 104: 976-997. https://doi.org/10.1603/AN10153

Happold D. \& Lock J.M. 2013. The biotic zones of Africa. In: Kingdon J., Happold D., Butynski T., Hoffmann M., Happold M. \& Kalina J. (eds) Mammals of Africa, Vol. 1: 57-74. Bloomsbury, London.

Hebert P.D.N., Cywinska A., Ball S.L. \& deWaard J.R. 2003a. Biological identifications through DNA barcodes. Proceedings of the Royal Society of London B 270: 313-321.

https://doi.org/10.1098/rspb.2002.2218

Hebert P.D.N., Ratnasingham S. \& DeWaard J.R. 2003b. Barcoding animal life: Cytochrome C oxidase subunit 1 divergences among closely related species. Proceedings of the Royal Society of London B 270: S96-S99. https://doi.org/10.1098/rsbl.2003.0025

Hull F.M. 1949. The morphology and inter-relationship of the genera of syrphid flies, recent and fossil. Transactions of the Zoological Society of London 26: 257-408.

https://doi.org/10.1111/j.1096-3642.1949.tb00224.x

Láska P., Bičík V., Dušek J., Mazánek L. \& Holinka J. 2000. Description of the puparia of Afrosyrphus varipes and Dideopsis aegrotus (Diptera, Syrphidae). Acta Universitatis Palackianae Olomucensis, Facultas Rerum Naturalium Biologica 38: 79-83.

Mazánek L., Láska P., Bičík V., Dušek J. \& Novotný R. 1999. Descriptions of puparia of Afrotropic species of Betasyrphus Matsumura (Diptera, Syrphidae). Acta Universitatis Palackianae Olomucensis, Facultas Rerum Naturalium Biologica 37: 89-98.

Miller M.A., Pfeiffer W. \& Schwartz T. 2010. Creating the CIPRES Science Gateway for inference of large phylogenetic trees. In: Proceedings of the Gateway Computing Environments Workshop (GCE), 14 Nov. 2010, New Orleans, LA: 1-8.

Rambaut A. 2009. FigTree ver. 1.3.1: Tree Figure Drawing Tool.

Available from http://tree.bio.ed.ac.uk/software/figtree/ [accessed 12 Jun. 2017].

Rogers P.C., O’Connell B., Mwang'ombe J., Madoffe S. \& Hertel G. 2008. Forest health monitoring in the Ngangao Forest, Taita Hills, Kenya: a five year assessment of change. Journal of East African Natural History 97 (1): 3-17. https://doi.org/10.2982/0012-8317(2008)97[3:FHMITN]2.0.CO;2

Rozo-Lopez P. \& Mengual X. 2015. Mosquito species (Diptera, Culicidae) in three ecosystems from the Colombian Andes: identification through DNA barcoding and adult morphology. ZooKeys 513: 39-64. https://doi.org/10.3897/zookeys.513.9561

Schmutterer H. 1972a. Untersuchungen über das Verhalten von zwei ostafrikanischen Ameisenarten gegenüber räuberischen Syrphiden. Entomophaga 17: 443-453.

Schmutterer H. 1972b. Zur Beutespezifität polyphager, räuberischer Syrphiden Ostafrikas. Zeitschrift für angewandte Entomologie 71: 278-286. https://doi.org/10.1111/j.1439-0418.1972.tb01749.x 
Schmutterer H. 1974. Ökologische Untersuchungen an entomophagen Syrphiden und ihren Parasiten im Hochland von Kenia (Ostafrika). Zeitschrift für angewandte Entomologie 75: 42-67. https://doi.org/10.1111/j.1439-0418.1974.tb01826.x

Shorthouse D.P. 2010. SimpleMappr, an Online Tool to Produce Publication-Quality Point Maps. Available from http://www.simplemappr.net [accessed 20 May 2019].

Skevington J.H. 2008. Hilltopping. In: Capinera J.L. (ed.) Encyclopedia of Entomology: 1799-1807. Springer, Dordrecht, the Netherlands.

Smith K.V.G. \& Vockeroth J.R. 1980. Family Syrphidae. In: Crosskey R.W. (ed.) Catalogue of the Diptera of the Afrotropical Region: 488-510. British Museum (Natural History), London.

Ssymank A. 2012. A contribution to the Syrphidae (Diptera) fauna of Cameroon, with a preliminary checklist of the family. African Invertebrates 53: 249-266. https://doi.org/10.5733/afin.053.0117

The Plant List. 2013. Version 1.1. Available from http://www.theplantlist.org/ [accessed 17 May 2019].

Thompson F.C. 1999. A key to the genera of the flower flies of the Neotropical Region including the descriptions of genera and species and a glossary of taxonomic terms. Contributions on Entomology, International 3 (3): 319-378. Available from http://hdl.handle.net/10088/17492 [accessed 2 Apr. 2020].

Thompson F.C. 2019. Syrphidae. Systema Dipterorum, version 2.4, 13,431 records. Available from http://sd.zoobank.org/ [accessed 10 Oct. 2019].

Toivonen T., Rikkinen J. \& Pellikka P. 2012. Landscapes and lichens of Taita Hills, Kenya. Helsingin Yliopiston Maantieteen Laitoksen Tutkimusretki Raportteja [Expedition Reports of the Department of Geography, University of Helsinki] 50: 1-93.

Useful Tropical Plants Database. 2019. Version from 13 Jun. 2019 with 11906 plants. Available from http://tropical.theferns.info/ [accessed 23 Oct. 2019].

Vockeroth J.R. 1969. A revision of the genera of the Syrphini (Diptera: Syrphidae). Memoirs of the Entomological Society of Canada 101 (S62): 5-176. https://doi.org/10.4039/entm10162fv

Wagura L. 2014. A Guide to Taita Hills. Unique Natural History. Published by the author.

Zwickl D.J. 2006. Genetic Algorithm Approaches for the Phylogenetic Analysis of Large Biological Sequence Datasets under the Maximum Likelihood Criterion. PhD Thesis. The University of Texas at Austin, Austin, TX. Available from http://hdl.handle.net/2152/2666 [accessed 2 Apr. 2020].

Zwickl D.J. 2011. GARLI (Genetic Algorithm for Rapid Likelihood Inference) version 2.01. Available from https://code.google.com/archive/p/garli/downloads [accessed 12 Jun. 2017].

Manuscript received: 14 November 2019

Manuscript accepted: 10 January 2020

Published on: 27 April 2020

Topic editor: Nesrine Akkari

Desk editor: Danny Eibye-Jacobsen

Printed versions of all papers are also deposited in the libraries of the institutes that are members of the EJT consortium: Muséum national d'histoire naturelle, Paris, France; Meise Botanic Garden, Belgium; Royal Museum for Central Africa, Tervuren, Belgium; Royal Belgian Institute of Natural Sciences, Brussels, Belgium; Natural History Museum of Denmark, Copenhagen, Denmark; Naturalis Biodiversity Center, Leiden, the Netherlands; Museo Nacional de Ciencias Naturales-CSIC, Madrid, Spain; Real Jardín Botánico de Madrid CSIC, Spain; Zoological Research Museum Alexander Koenig, Bonn, Germany; National Museum, Prague, Czech Republic. 